\title{
Меры уголовно-правового характера и уголовная ответственность: научная Аискуссия и поиск решения
}

\section{ю. Е. ПУдОВОЧкИн}

Российский государственный университет правосудия, г. Москва, Российская Федерация

ORCID: https://orcid. org/0000-0003-1100-9310, e-mail: 11081975@list.ru

\begin{abstract}
Р е фе рат. В статье анализируется содержание научной дискуссии о соотношении уголовной ответственности и мер уголовно-правового характера и доказывается, что соответствующие понятия не являются соподчиненными и взаимозаменяемыми. Меры уголовно-правового характера определяются как установленные законом юридические средства, нормативные конструкции, при помощи которых государство реагирует на преступление. Уголовная ответственность определяется как реальное явление, особое сочетание мер уголовно-правового характера, реализуемое на основании приговора суда. Общность ответственности и мер уголовно-правового характера состоит в том, что они могут применяться только в случае совершения преступления. В связи с этим меры, назначаемые лицам, совершившим общественно опасное деяние до достижения возраста уголовной ответственности или в состоянии невменяемости, надо исключить из списка мер уголовно-правового характера. Различие ответственности и мер уголовно-правового характера состоит в том, что ответственность требует официального признания лица виновным в совершении преступления, тогда как меры уголовно-правового характера могут применяться и в отсутствие решения вопроса о виновности, при освобождении лица от уголовной ответственности. Исходя из этого все меры уголовно-правового характера подразделяются на две группы: а) меры, применяемые вне рамок ответственности, б) меры, выступающие частью ответственности. Представлена номенклатура каждой из них, определены перспективные возможности их расширения. В частности, список мер уголовно-правового характера может быть дополнен общественными работами, ограниченно оплачиваемыми работами и административным надзором.

Ключевые слова: уголовная ответственность; меры уголовно-правового характера; уголовное наказание; условное осуждение; судимость; административный надзор; уголовно-правовое отношение.
\end{abstract}

12.00.08 - Уголовное право и криминология; уголовно-исполнительное право.

Для цитирования: Пудовочкин Ю. Е. Меры уголовно-правового характера и уголовная ответственность: научная дискуссия и поиск решения. Пенитенциарная наука. 2020, т. 14, № 4 (52), с. 460-472. DOI 10.46741/2686-9764-2020-14-4-460-472.

\section{Criminal law measures and criminal liability: scientific discussion and search for solutions}

\section{YURII E. PUDOVOCHKIN}

Criminal Law Measures and Criminal Liability: Scientific Discussion and Searching for a Solution Russian State University of Justice, Moscow, Russian Federation

ORCID: https://orcid. org/0000-0003-1100-9310, e-mail: 11081975@list.ru

A b s tract. The paper analyzes the content of scientific discourse on the relationship between criminal liability and criminal law measures and proves that the corresponding concepts are not subordinate and interchangeable. Criminal law measures are defined as legal means and normative structures established by law, which the state uses to respond 
to a crime. Criminal liability is defined as a real phenomenon, a special combination of criminal law measures implemented on the basis of a court sentence. The common feature of criminal liability and criminal law measures is that they can only be applied in case of commission of a crime. In this regard, measures imposed on persons who have committed a socially dangerous act before reaching the age of criminal liability or in a state of insanity should be excluded from the list of measures of a criminal legal nature. The difference between liability and criminal law measures is that liability requires official recognition of a person guilty of committing a crime, while criminal law measures can also be applied in the absence of a decision on guilt, when a person is exempt from criminal liability. Based on this, all criminal law measures are divided into two groups: a) measures applied outside the scope of liability, and b) measures that are part of liability. We give the nomenclature of each of them and identify promising opportunities for their expansion. In particular, the list of criminal law measures may be supplemented with community service, limited paid work, and administrative supervision.

Key words: criminal liability; measures of a criminal-legal nature; criminal punishment; conditional conviction; criminal record; administrative supervision; criminallegal attitude.

12.00.08 - Criminal law and criminology; penal law.

For citation: Pudovochkin Yu.E. Criminal law measures and criminal liability: scientific discussion and searching for a solution. Penitentiary Science, 2020, vol. 14, no. 4 (52), pp. 460-472. DOI 10.46741/2686-9764-2020-14-4-460-472.

Признавая меры уголовно-правового характера правовым средством, при помощи которого в рамках уголовно-правовых отношений государство корректирует правовой статус лица, совершившего преступление, необходимо рассмотреть наиболее значимый вопрос о соотношении мер уголовноправового характера и уголовной ответственности.

Современное уголовное законодательство в этой части дает основания для самых различных трактовок.

В ст. 2, 6 и 7 УК РФ, где встречается понятие «меры уголовно-правового характера», оно употребляется в общем смысловом ряду с наказанием. Но поскольку наказание немыслимо без уголовной ответственности, то соответствующие законодательные формулировки дают основание юристам рассматривать меры уголовно-правового характера в качестве составной части уголовной ответственности. Так, А. В. Наумов утверждает, что «под уголовной ответственностью следует понимать все меры уголовно-правового воздействия, применяемые к лицу, совершившему преступление... Уголовная ответственность подразделяется на наказание и иные меры уголовно-правового воздействия (например, меры медицинского характера), не являющиеся наказанием» [32, с. 96]. В подобных рассуждениях уголовная ответственность выступает родовым понятием по отношению к наказанию и иным мерам уголовно-правового характера.

В то же время в ст. 6 и 7 УК РФ утверждается, что меры уголовно-правового характера применяются к лицу, совершившему преступление, при этом разд. VI УК РФ к мерам уголовно-правового характера относит принудительные меры медицинского характера, которые назначаются среди прочего лицам, состояние невменяемости которых в момент совершения предусмотренного уголовного законом деяния не позволяет рассматривать последнее в качестве преступления. Указанные нормативные предписания позволяют юристам говорить об ином соотношении уголовной ответственности и мер уголовно-правового характера. В частности, В. В. Мальцев пишет, что «гораздо больше аргументов в пользу того, что как раз содержание понятия "меры уголовно-правового характера" включает в себя содержание понятия "уголовная ответственность", чем наоборот» [25, с. 184185]. Аналогичного мнения придерживается Н. А. Лопашенко, которая усматривает наличие следующего соотношения обсуждаемых понятий: «меры уголовно-правового характера включают в себя уголовную ответственность и иные меры уголовно-правового характера» [23, с. 66].

Как видим, рассматриваемый вопрос весьма дискуссионен. Основная проблема, решение которой разводит юристов по разным полюсам, состоит в следующем: являются ли меры уголовно-правового характера проявлением уголовной ответственности либо ее альтернативой или, напротив, уголовная ответственность есть одна из мер уголовно-правового характера?

Проблема многократно осложняется дискуссией по поводу самой уголовной ответственности. Так, например, Н. В. Щедрин, 
рассуждая о введенных в УК РФ новых мерах уголовно-правового характера, пишет, что «восприятие существа новеллы затрудняет "бородатая" дискуссия о понятии уголовной ответственности и формах ее реализации. Представляется, что категория "уголовная ответственность" создает ненужные коллизии на практике, а также порождает бесконечные споры в теории». Далее автор задается вопросом: «Хотелось бы узнать, какие "ужасные потери" нас ожидают, если мы уберем этот термин из уголовного законодательства? Вместо него можно использовать обобщающий термин "уголовно-правовое воздействие", "меры уголовно-правового характера" или просто "уголовно-правовые санкции"... А вот выгоды от такого шага несомненны. Одна из них состоит в том, что будет положен конец бесплодным дискуссиям по поводу объема, форм реализации уголовной ответственности, момента ее возникновения и прекращения» [44, с. 46].

Столь пространная цитата, хотя и исчерпывает рассуждения Н. В. Щедрина о бесполезности категории уголовной ответственности, тем не менее не содержит, по сути, ни одного весомого аргумента против использования категории «уголовная ответственность», кроме необходимости прекращения дискуссии. Да и тот нельзя принимать во внимание, поскольку, как представляется, в рассматриваемом случае выход из проблемной ситуации состоит не в прекращении дискуссии, а напротив, в ее углублении, выводе научной полемики на более высокий, методологически важный уровень.

Как известно, категория уголовной ответственности наполнилась современным смыслом в середине прошлого века в связи с необходимостью, с одной стороны, интегрировать все меры воздействия на преступника, а с другой - отделить некоторые из этих мер от уголовного наказания и мер не уголовно-правового характера. Сегодня потребность в инструментальном сопровождении данной функции не только не исчезла, но напротив, обострилась.

Не ставя своей задачей полноценный анализ этой категории, тем более что данной теме посвящен значительный объем научной литературы, отметим лишь, что ценность категории уголовной ответственности для надлежащего понимания мер уголовно-правового характера напрямую зависит от того, что именно вкладывается в понятие самой уголовной ответственности.

По нашему убеждению, из большого количества существующих концепций наиболее убедительной представляется та, в рамках которой уголовная ответственность понимается как основанное на законе и выраженное в приговоре суда ухудшение правового статуса лица, совершившего преступление, заключающееся в лишении или ограничении некоторых его прав и свобод [26, с. 52; 40, с. 104]. Такой подход предполагает, что ответственность как некий феномен может существовать лишь в рамках реально имеющихся и развивающихся охранительных общественных отношений, порожденных преступлением [19, с. 26; 22, с. 33] и что ответственность - это «явление объективной действительности» [43, с. 100].

Если исходить из этих позиций, придется констатировать очевидный факт: ответственность - это нечто из области реальных отношений, она всегда индивидуальна. Меры уголовно-правового характера изначально находятся в совершенно иной плоскости. Будучи установленными законом средствами правового регулирования возникающих в связи с преступлением отношений, они прежде всего относятся к сфере нормативных конструкций. Иными словами, если ответственность - это некий элемент реализации, динамики уголовно-правовых предписаний, то меры уголовно-правового характера - элемент статичный, если допустимо так выразиться, модельно-нормативный. Они могут стать элементом действительности только в том случае, если будут реально применены к лицу, совершившему преступление, то есть когда будут выступать частью ответственности.

Предложенное объяснение уголовной ответственности, на наш взгляд, убеждает в необходимости и полезности данной научной и нормативной категории для понимания и совершенствования механизма уголовно-правового регулирования, хотя и не отвечает на вопрос о соотношении объемов понятий «ответственность» и «меры уголовно-правового характера».

Представляется, что выраженное в уголовной ответственности ограничение правового статуса лица, совершившего преступление, происходит за счет применения к нему тех или иных мер уголовно-правового характера, а реализация данных мер составляет содержание уголовной ответственности. Означает ли это, что в представленной выше дискуссии рассуждение А. В. Наумова о том, что меры уголовно-правового характера являются частью ответственности, следует признать единственно верным? Полагаем, что нет. 
Как известно, уголовный закон допускает применение мер уголовно-правового характера и за рамками реализации уголовной ответственности. Заметим, речь идет лишь о мерах, которые применяются к лицам, совершившим именно преступление (что исключает из сферы анализа меры, применяемые к невменяемым лицам и лицам, не достигшим возраста уголовной ответственности, которые, по нашему убеждению, должны располагаться за пределами уголовного закона). В этом случае их осуществление происходит при освобождении от ответственности. Этот институт в последнее время стал весьма востребованным. Не углубляясь в его анализ, укажем, что некоторыми специалистами такое освобождение признается формой реализации уголовной ответственности [2, с. 13; 17, с. 101]. Следовательно, исходя из логики признания всех форм реализации ответственности мерами уголовно-правового характера, само освобождение от уголовной ответственности должно рассматриваться в качестве одной из таких мер. Об это прямо пишут в своих работах И. Э. Звечаровский [11; 35], В. К. Дуюнов [7, с. 68], Г. В. Назаренко [31, с. 266]. Вместе с тем, на наш взгляд, ошибочность такого вывода кроется в небезупречности исходной посылки.

Если при освобождении от уголовной ответственности лицо, совершившее преступление, освобождается от официальной отрицательной оценки своего поведения как преступного и необходимости перенести некоторые правоограничения, выраженные в приговоре суда, если он не претерпевает реальных правоограничений, то освобождение от ответственности не может служить формой реализации этой ответственности. Отсутствие чего-либо по определению не может быть формой реализации этого чегото [9, c. 25].

При освобождении от уголовной ответственности происходит прекращение (иногда приостановление) уголовно-правового отношения по воле государства. Обладая своего рода субъективным правом на привлечение преступников к ответственности и их наказание, государство (при наличии установленных им в законе условий), по собственной воле и руководствуясь собственными соображениями, связанными с гуманизмом, справедливостью, целесообразностью и пр., разрывает правовую связь с лицом, совершившим преступление, отказывается от реализации принадлежащего ему права. По общему правилу никакие реальные карательные или иные меры воздействия в отношении лица, совершившего преступление, при этом не применяются. Следовательно, само по себе освобождение от уголовной ответственности не относится к мерам уголовно-правового характера.

Однако из этого правила есть значимые исключения (ст. 76.2, 90 УК РФ). Определить правовую природу мер, которые могут применяться к лицу, совершившему преступление, при освобождении его от уголовной ответственности, весьма сложно. Сегодня это принудительные меры воспитательного воздействия и судебный штраф, а в перспективе, при условии реализации законодательной инициативы Верховного Суда Российской Федерации о введении в УК РФ категории уголовного проступка, и иные меры уголовно-правового характера. Значительная часть указанных ранее авторов признает их мерами уголовно-правового характера. При этом, однако, не всегда учитывается, например, то обстоятельство, что принудительные меры воспитательного воздействия могут применяться к трем категориям подростков: несовершеннолетним лицам, не подлежащим уголовной ответственности в силу недостижения возраста либо отставания в психическом развитии, не связанного с психическим расстройством; освобожденным от уголовной ответственности; освобожденным от уголовного наказания. В силу этого сложно в полной мере согласиться с мнением С. А. Боровикова, который предлагает игнорировать указанные различия и в любом случае относить меры воспитательного воздействия к мерам уголовно-правового характера [1, с. 16]. Иначе рассуждает А. В. Бриллиантов, утверждающий, что при применении ст. 90 УК РФ меры воспитательного воздействия в содержание уголовной ответственности, от которой лицо освобождается, не входят [2, с. 8]. Трудно разделить данную точку зрения, поскольку правовая природа тех или иных мер воздействия не может всецело определяться лишь процессуальным порядком их применения. О единой природе рассматриваемых мер пишут и иные авторы, которые в то же время усматривают в них меры не уголовно-правового, а административно-правового [15, с. 113] или общественного [35, с. 15-16] воздействия.

Представляя собственный взгляд на проблему, остановим внимание на следующих, как нам представляется, очевидных фактах:

1) меры, применяемые при отсутствии оснований для привлечения к уголовной 
ответственности (меры медицинского характера в отношении невменяемых и меры воспитательного воздействия в отношении лиц, не достигших возраста уголовной ответственности), не относятся к разряду уголовно-правовых;

2) меры, применяемые к лицам, совершившим преступление в рамках реализации их уголовной ответственности (меры медицинского характера в отношении ограниченно вменяемых, конфискация имущества), выступают частью уголовной ответственности;

3) меры, применяемые при освобождении от уголовной ответственности лиц, совершивших преступления (меры воспитательного воздействия, судебный штраф), не составляя части уголовной ответственности, сохраняют свойство мер уголовно-правового характера.

Таким образом, не все меры уголовноправового характера являются частью ответственности, отношение между ними не является отношением соподчинения (части и целого). Однако это не дает аргументов и в пользу позиции В. В. Мальцева и Н. А. Лопашенко в представленной выше теоретической дискуссии, поскольку уголовная ответственность вовсе не обязательно выступает элементом мер уголовно-правового характера.

В данном случае нет оснований для обвинения специалистов в противоречивости представленных позиций или тем более их ошибочности. Нельзя не учитывать то немаловажное обстоятельство, что многие теоретические взгляды формировались и презентовались в ситуации действия уголовного закона, существенно отличающегося своим содержанием от действующей редакции. В этом отношении обе представленные точки зрения, находясь по разные стороны в теоретическом споре, на наш взгляд, объективно не учитывают кардинальных трансформаций уголовного законодательства и уже только в силу этого неточны.

Меры уголовно-правового характера в действующем УК РФ не образуют однородной группы. Часть этих мер применяется за рамками ответственности, другая - в ее рамках. Причем важно, что эти меры не пересекаются (принудительные меры воспитательного воздействия могут применяться в порядке ст. 90 УК РФ при освобождении от ответственности и в порядке ст. 92 УК РФ при освобождении от уголовного наказания, но это исключение, которое требует специаль- ного исследования и, возможно, устранения). В силу этого выстраивать однозначные и линейные связи между ответственностью и указанными мерами логически неверно. Установление такой связи должно сопровождаться дифференцированным анализом мер уголовно-правового характера.

Итак, изложенное позволяет провести первую градацию мер уголовно-правового характера по признаку их соотношения с уголовной ответственностью. Первую группу образуют меры уголовно-правового характера, применяемые при освобождении лица, совершившего преступление, от уголовной ответственности. Таковыми, согласно закону, являются принудительные меры воспитательного воздействия (ст. 90 УК РФ) и судебный штраф (ст. 104.4 УК РФ). В перспективе не исключено дополнение этого списка общественными работами и ограниченно оплачиваемыми работами.

Вторую группу составляют меры уголовно-правового характера, которые применяются в рамках уголовной ответственности. Определение их перечня представляет собой отдельную исследовательскую задачу. Отталкиваясь от идеи о признании мер уголовно-правового характера элементом уголовной ответственности, специалисты весьма различно решают вопрос о том, какие именно правовые средства воздействия на правовой статус лица в рамках ответственности выступают мерами уголовноправового характера. Так, представляется возможным в рамках этого направления научной мысли обозначить три ключевых подхода.

Самую широкую интерпретацию мер уголовно-правового характера предложил И. Э. Звечаровский. Он понимает под ними предусмотренные уголовным законом меры, применяемые независимо от юридической природы поведения лица, совершившего преступление, но с учетом изменений его уголовно-правового статуса. Такая трактовка позволила автору не только отнести к исследуемым мерам «гуманистические альтернативы» (все виды освобождения от уголовной ответственности, добровольный отказ от преступления, амнистию), но и учесть существование уголовно-правовых норм, в которых получает оценку отрицательное поведение лица после совершения им преступления (ч. 4 ст. 50 УК) [11, с. 35].

Близки к изложенной точке зрения и рассуждения С. И. Курганова, который предлагает в качестве оснований применения иных мер уголовно-правового характера 
рассматривать в целом правонарушающее постпреступное поведение лица и относить к ним, помимо форм реализации уголовной ответственности, меры, применяемые к осужденным, не исполняющим требования приговора суда (отмену условного осуждения или продление испытательного срока (ч. 2, 3 ст. 74 УК РФ), отмену условно-досрочного освобождения (п. «а» ч. 7 ст. 79 УК РФ), отмену принудительной меры воспитательного воздействия, которая применялась при освобождении от уголовной ответственности (ч. 4 ст. 90 УК РФ), отмену отсрочки отбывания наказания беременным женщинам и женщинам, имеющим малолетних детей (ч. 2 ст. 82 УК РФ), замену наказания в случае злостного уклонения от его отбывания на более строгое (ч. 5 ст. 46, ч. 3 ст. 49, ч. 4 ст. 50, ч. 4 ст. 51 УК РФ)) [21, с. 59].

В данном случае мерами уголовно-правового характера объявляются все без исключения средства реагирования государства на абсолютно любое жизненное обстоятельство, признаваемое в уголовном праве юридическим фактом. На наш взгляд, такая концепция допускает неоправданно широкое толкование исследуемого феномена, включая в единую систему мер уголовно-правового характера принципиально различные по основаниям, целям и правовой природе меры. Замена назначенного наказания более строгим видом, отмена условного осуждения, отмена отсрочки отбывания наказания, отмена освобождения от уголовной ответственности - это не сами по себе меры уголовно-правового характера (материально-правовой феномен, правовое средство разрешения конфликта, вызванного преступлением), а скорее, правовые последствия нарушения уже урегулированных уголовным законом охранительных отношений между преступником и государством. Иными словами, эти средства направлены не на урегулирование уголовно-правового отношения, а на обеспечение незыблемости выраженного в приговоре или ином процессуальном акте варианта разрешения уголовно-правового конфликта. Они носят, таким образом, вторичный, обеспечительный характер. И уже в силу этого нельзя уравнивать их правовую природу с правовой природой мер уголовно-правового характера, которые служат реакцией именно на совершенное преступление, а не на постпреступное противоправное поведение.

Второй подход к пониманию мер уголовно-правового характера образуют воззрения группы авторов, вводящих дополнительные критерии отнесения мер к уголовно-правовым и дающих их ограничительное толкование. Так, С. В. Землюков признает, что меры уголовно-правового характера применяются только к лицам, совершившим преступления, и направлены на решение задач уголовного права. Вместе с тем он полагает, что «иные меры уголовно-правового характера - это закрепленные в Уголовном кодексе меры воздействия, применяемые органами дознания, следствия или суда к лицу, совершившему преступление, взамен уголовной ответственности либо наказания и имеющие целью экономию мер уголовной репрессии, исправление лица и предупреждение совершения им новых преступлений» [12, с. 32]. К такого рода гуманистическим альтернативам C. В. Землюков относит меры, применяемые при освобождении от уголовной ответственности (ст. 90 УК РФ), меры, применяемые при освобождении от уголовного наказания (ст. 92 УК РФ), условное осуждение (ст. 73 УК РФ).

Гуманистической альтернативой наказанию признает меры уголовно-правового характера и В. М. Степашин [34, с. 398]. Схожими с приведенными следует признать рассуждения М. Ф. Гареева, который все связанные с ответственностью уголовно-правовые меры воздействия на лиц, виновных в преступлении, классифицирует следующим образом: 1) наказание и 2) иные некарательные меры уголовно-правового характера [3, с. 10]. На этих же позициях строит свою концепцию С. Ю. Скобелин: под иными мерами уголовно-правового характера он понимает иные, кроме наказания, формы реализации уголовной ответственности, которые могут применяться к лицу, совершившему преступление. Такие меры, по его мнению, носят правоограничивающий, но не карающий, а воспитательно-предупредительный характер [38, с. 61].

При некоторых существующих отличиях общими для представленных теорий являются признание специалистами наказания одной из мер уголовно-правового характера и ограничительное понимание иных мер только как гуманистической альтернативы наказанию.

Наконец, третий подход к пониманию мер уголовно-правового характера формируют специалисты, которые, признавая основанием применения исследуемых мер факт совершения преступления (и исключая тем самым из круга мер обеспечительные средства), тем не менее рассматривают иные меры уголовно-правового характера в ка- 
честве не только альтернативы уголовному наказанию, но и его дополнения. Такие суждения высказаны авторами, разделяющими меры уголовно-правового характера на дополняющие наказание и выступающие его альтернативой [3, с. 17; 27, с. 46; 30, с. 7].

Анализируя представленные в отечественной науке подходы к пониманию мер уголовно-правового характера, следует признать, что каждый из них не только имеет право на существование, но и обладает определенным познавательным потенциалом, раскрывая, высвечивая ту или иную грань, свойство, признак данных мер. Вряд ли можно однозначно говорить о справедливости или несправедливости любого из них. Речь должна идти лишь о больших или меньших предпочтениях в отношении концепции, которая соответствует (или не соответствует) авторскому пониманию сути механизма уголовного права. Фактически любая частная теория мер уголовно-правового характера является базовой, определяющей для понимания уголовного права в целом, поскольку именно в ней перекрещиваются представления о предмете и методе уголовного права, юридических фактах, субъектах уголовно-правовых отношений, цели уголовно-правового регулирования и пр. В силу этого любая критика такой теории требует многочисленных предварительных оговорок относительно авторского понимания уголовного права. Она может быть плодотворной лишь при условии, что оппоненты говорят на одном языке, в рамках единой, разделяемой сторонами научной парадигмы.

Учитывая это, как уже отмечалось, мы не обращаемся к анализу концепций, признающих мерами уголовно-правового характера те, что применяются в случае отсутствия в содеянном признаков состава преступления. Оставляем в стороне и те меры уголовно-правового характера, которые применяются при освобождении лица от уголовной ответственности. Ограничимся только теми мерами, которые предусмотрены для лиц, способных нести уголовную ответственность, и являются частью последней.

Но здесь возникает проблема, без обсуждения которой дальнейший научный поиск затруднителен. Речь идет о содержании и формах реализации уголовной ответственности. Полноценный анализ этого вопроса в рамках статьи вряд ли необходим, а потому обратим внимание лишь на некоторые аспекты темы, имеющие непосредственное отношение к пониманию мер уголовно-правового характера.
Полагаем, не способен вызывать серьезную критику в науке тезис о том, что содержанием уголовной ответственности следует признавать осуждение лица и совершенного им деяния от имени государства в обвинительном приговоре суда, меры воздействия на это лицо, определяемые в приговоре суда на основании уголовного закона, а также судимость. В зависимости от того, какие именно меры воздействия определены в приговоре и каков порядок их исполнения, можно вести речь о различных формах реализации уголовной ответственности. Форма реализации уголовной ответственности не зависит от факта осуждения (он универсален и присутствует во всех случаях реализации уголовной ответственности). Она определяется как раз «серединной частью» содержания ответственности, то есть применяемыми государством мерами, тем или иным порядком их реализации, возможностью сочетания различных мер.

До недавнего прошлого закон знал только одну меру - наказание, различные вариации назначения которого определяли форму реализации уголовной ответственности. Сегодня в ряду мер, реализуемых в рамках ответственности, появились и меры уголовно-правового характера, отличные от наказания. Закон прямо называет только три таких правовых средства: меры воспитательного воздействия, которые применяются при освобождении от уголовного наказания (ст. 92 УК РФ), принудительное наблюдение и лечение у врача-психиатра в амбулаторных условиях (ч. 2 ст. 99 УК РФ), конфискацию имущества (ст. 104.1 УК РФ).

В уголовно-правовой литературе этот список иногда корректируется прежде всего в связи с обсуждением таких уголовно-правовых институтов, как условное осуждение и освобождение от уголовного наказания.

Ряд специалистов усматривают в освобождении от наказания самостоятельную меру уголовно-правового характера [11, с. $35 ; 16$, с. 287; 31, с. 266]; еще больше сторонников приобрело признание мерой уголовно-правового характера условного осуждения [18, с. 57 ; 20, с. 24; 29, с. 23-25; 33, с. 88; 39, с. 290]; группа авторов мерами уголовно-правого характера признает не само по себе условное осуждение или освобождение от наказания, а те ограничения и обязанности, которые возлагаются на условно осужденных или освобожденных от наказания [6, с. 128; 8, с. 211; 14, с. 173].

Представляется, что при всей внешней схожести условное осуждение и освобож- 
дение от наказания требуют раздельного анализа.

В ситуации освобождения от уголовного наказания назначаемой в приговоре суда мерой уголовно-правового характера выступает прежде всего уголовное наказание. Особый порядок исполнения этого наказания является обстоятельством, которое определяет форму реализации уголовной ответственности, но не выступает самостоятельной мерой уголовно-правового характера. Возможные требования к поведению лиц, освобожденных от ответственности, включая их обязанности воспитывать детей или пройти курс медико-социальной реабилитации, также следует рассматривать не в качестве самостоятельных мер уголовноправового характера, которые назначаются за совершение преступления, а в качестве предусмотренных законом последствий оценки тех или иных юридических фактов, которые влияют на динамику уже существующего уголовно-правового отношения, то есть в качестве уголовно-правовых последствий.

Что касается условного осуждения, то, не имея цели вступать в давний и непрекращающийся спор относительно правовой природы этой меры, позволим себе в этой части исследования без дополнительных аргументов поддержать уже высказанное в науке мнение и соотнести его с интересующим нас предметом. Единственной значимой оговоркой в данном случае будет вопрос о том, признавать ли мерой уголовно-правового характера собственно условное осуждение или меры, которые применяются по приговору суда к условно осужденным в целях их исправления и предупреждения новых преступлений. Представляется, что условное осуждение само по себе выступает формой реализации уголовной ответственности, при которой назначается две меры уголовно-правового характера: одна (наказание) обязательно и условно, вторая (ограничения и требования к поведению) - альтернативно, но реально. В этой связи при обсуждении условного осуждения в контексте учения о мерах уголовно-правового характера целесообразно специальными, самостоятельными мерами считать все-таки не условное осуждение в целом, а именно те назначенные по приговору суда меры, исполнение которых выступает условием, позволяющим не исполнять уголовное наказание. Как верно замечают специалисты, «институт условного осуждения в том виде, в котором он закреплен в действующем УК, представляет со- бой не что иное, как сочетание применения двух самостоятельных инструментов уголовно-правового принуждения: наказания и испытания. Отсюда более правильно рассматривать условное осуждение не как одно из проявлений наказания или испытания по отдельности, а как форму реализации уголовной ответственности... Исходя из такого подхода к пониманию смысла условного осуждения неизбежно возникает <вопрос> о статусе испытания. Вполне очевидно, что это самостоятельная мера уголовно-правового характера, которая по своей сути выступает альтернативным наказанию средством уголовной ответственности. Потому она заслуживает отдельного места в уголовном законе» [28, с. 109].

Отдельного внимания в рамках обсуждения вопроса о связи мер уголовно-правового характера и содержания уголовной ответственности заслуживает оценка судимости. В современной науке она рассматривается весьма неоднозначно. Традиционным можно считать взгляд на судимость и связанные с ней правоограничения как составную часть уголовной ответственности [10, с. 39-40; 24, с. 11]. В то же время В. В. Мальцев пишет: «Судимость по закону не может выступать (что важно, и не выступает) в качестве средства лишения или ограничения прав и свобод лиц, отбывших наказание, но имеющих непогашенную или неснятую судимость. Отсюда, не входя в противоречие с уголовным законом, ее нельзя считать "ни несением бремени ответственности" либо продолжением наказания, ни уголовной ответственностью в форме наказания. Никаких ограничений в реализации прав и свобод человека и гражданина в связи с судимостью не зафиксировано и в Конституции, нормативных актах других отраслей права. Отсюда наличие судимости в целом не ухудшает правового статуса лиц, отбывших наказание» [25, с. 202; 26, с. 67]. Думается, что это не совсем так. Перечень правоограничений, которые законом возлагаются на лиц, имеющих судимость, крайне широк. В связи с этим возникает потребность в определении их природы, а также природы самой судимости.

Так, например, ст. 45 Уголовного кодекса Республики Беларусь связывает судимость с самим фактом осуждения и признает ее последствием осуждения, которое создает предпосылки для применения наказания или иных мер уголовно-правового характера: «осуждение лица за совершенное им преступление создает правовое состояние судимости, заключающееся в возможности 
применения к осужденному наказания либо иных мер уголовной ответственности в соответствии с приговором суда и настоящим Кодексом» [42]. А. В. Бриллиантов пишет, что судимость как определенное правовое состояние лица является не составной частью уголовной ответственности и не ее предпосылкой, а последствием [41, с. 71]. Конституционный Суд Российской Федерации в постановлении от 19.03.2003 № 3-П «По делу о проверке конституционности положений Уголовного кодекса Российской Федерации, регламентирующих правовые последствия судимости лица, неоднократности и рецидива преступлений, а также пунктов 1-8 Постановления Государственной Думы от 26 мая 2000 года "Об объявлении амнистии в связи с 55-летием Победы в Великой Отечественной войне 1941-1945 годов" в связи с запросом Останкинского межмуниципального (районного) суда города Москвы и жалобами ряда граждан» определил судимость как «правовое состояние лица, обусловленное фактом осуждения и назначения ему по приговору суда наказания за совершенное преступление». С. Г. Келина указывала, что судимость является мерой уголовно-правового характера [16, с. 287].

Как видим, разброс мнений велик. Оценивая их, прежде всего укажем на недопустимость признания судимости самостоятельной мерой уголовно-правового характера. Она не закреплена в качестве таковой в законе и не является ею по существу, поскольку не предполагает некоего материализованного выражения в виде тех или иных ограничений. Вряд ли верно определять судимость как последствие осуждения или уголовной ответственности. Судимость, как это следует из положений ст. 86 УК РФ, порождается не просто осуждением лица, но назначением лицу уголовного наказания. В связи с этим подход, предложенный Конституционным Судом Российской Федерации, можно признать оптимальным.

Вместе с тем судимость, как известно, предполагает определенные правоограничения, находящиеся за пределами уголовного закона. В науке отмечалось, что ограничения общеправового характера не входят в содержание судимости [5, с. 8]. С этим сложно согласиться, учитывая, что непосредственно в УК РФ никаких правоограничений, связанных с судимостью, не установлено. Они все закреплены в законах иной отраслевой принадлежности. Трудовое законодательство, законодательство о военной службе, избирательное, конституцион- ное законодательство содержат целый ряд весьма существенных правоограничений для лиц, имеющих судимость. Кроме того, наличие судимости является непременным условием применения к некоторым лицам такой меры правового воздействия, как административный надзор, согласно Федеральному закону от 06.03.2011 № 64-Ф3 «Об административном надзоре за лицами, освобождаемыми из мест лишения свободы» [13, с. 307].

Говорить, что все эти меры не ограничивают правовой статус судимых, бессмысленно, равно как невозможно отрицать связь этих ограничений с совершенным преступлением. Поэтому справедливым будет не изымать состояние судимости из содержания ответственности, не исключать связь общегражданских правоограничений с судимостью, а напротив, включать обусловленные судимостью меры правоограничительного свойства в орбиту анализа мер уголовно-правового характера, прежде всего на предмет решения принципиального вопроса о том, могут ли какие-либо связанные с судимостью правоограничения быть признаны ограничениями уголовно-правового характера. Нельзя, полагаем, считать, что все такие правоограничения являются мерами уголовно-правового характера, но некоторые из них вполне могут обладать такой природой. Понимая, что решение этого сложного вопроса требует отдельного исследования, позволим себе без дополнительных аргументов присоединиться к высказанной в науке точке зрения о том, что административный надзор в полной мере отвечает признакам меры уголовно-правового характера [36, с. 98-103].

Еще одной важной теоретической проблемой в рамках учения об уголовной ответственности и мерах уголовно-правового характера является их соотношение с санкцией уголовно-правовой нормы. Под санкцией понимается та часть нормы, которая содержит описание видов и размеров наказаний, возможных в случае совершения преступления, описанного в диспозиции этой статьи. Поскольку наиболее древней и классической формой ответственности выступает предусмотренное санкцией наказание, ответственность обычно выглядит как реализация санкции. Практически об этом пишет А. А. Магомедов: «уголовная ответственность есть реализация в форме охранительного уголовного правоотношения уголовно-правовой нормы» [24, с. 32-33]. Но в целом ряде случаев предусмотренное 
санкцией наказание становится либо чрезмерным, либо недостаточным. С учетом некоторых относительно часто встречающихся индивидуальных особенностей преступления законодатель предусматривает дополнительные средства дифференциации ответственности, позволяющие корректировать санкцию за счет применения к виновным иных мер воздействия. При этом, исходя из соображений системности права и законодательной техники, данные средства помещаются за пределами санкции Особенной части УК РФ. На соответствующий признак иных мер уголовно-правового характера уже обратили внимание специалисты [16, с. 285; 37, с. 322]. Полностью признавая его наличие, подчеркнем, что он заставляет корректировать представления либо об ответственности как реализации санкции, либо о санкции как описании лишь наказаний. В любом случае этот факт позволяет уточнить крайне важный признак мер уголовно-правового характера: они могут выступать либо альтернативой уголовному наказанию, либо его дополнением.

Осуществленный сквозь призму предмета настоящего исследования далеко не полный анализ содержания и форм реализации уголовной ответственности позволяет плотнее приблизиться к пониманию сути и номенклатуры мер уголовно-правового характера, той их разновидности, что выступает частью уголовной ответственности. Полагаем возможным поддержать в данном случае точку зрения В. И. Горобцова, который к числу мер уголовно-правового характера причислял наказание, принудительные меры воспитательного воздействия, принудительные меры медицинского характера и условное осуждение [4, с. 36], а также разделить позицию Т. Г. Понятовской о возможности отнесения к таким мерам административного надзора.
Все эти меры (по аналогии с видами наказаний в ст. 45 УК РФ) могут быть поделены на основные, которые назначаются самостоятельно и не могут быть соединены с другими мерами, и дополнительные, которые назначаются только в совокупности с какой-нибудь основной мерой уголовноправового характера. Альтернативные наказанию меры уголовно-правового характера, применяемые к несовершеннолетним, условное осуждение являются основными, а принудительное лечение, конфискация имущества и административный надзор дополнительными мерами уголовно-правового характера.

Подведем итог:

1. Меры уголовно-правового характера не представляют собой однородной группы и в зависимости от их соотношения с уголовной ответственностью могут быть классифицированы на две группы: а) меры, применяемые вне рамок ответственности, б) меры, выступающие частью ответственности. Общим интегративным признаком этих мер выступает их основание - совершение преступления, общим разграничительным признаком - наличие или отсутствие официального осуждения лица в приговоре суда.

2. Мерами уголовно-правового характера, не связанными с реализацией уголовной ответственности, выступают принудительные меры воспитательного воздействия и судебный штраф, а в перспективе - общественные работы и ограниченно оплачиваемые работы.

3. Меры уголовно-правового характера, реализуемые в рамках уголовной ответственности, подразделяются на основные (уголовное наказание, принудительные меры воспитательного воздействия, условное осуждение) и дополнительные (принудительное лечение, конфискация имущества, а в перспективе - административный надзор).

\section{СПИСОК ЛИТЕРАТУРЫ}

1. Боровиков, С. А. Принудительные меры воспитательного воздействия как альтернатива наказанию несовершеннолетних / С. А. Боровиков. - Москва : Юрлитинформ, 2008. - 192 с. - ISBN 978-5-93295-430-0.

2. Бриллиантов, А. В. Освобождение от уголовной ответственности: с учетом обобщения судебной практики : научно-практическое пособие / А. В. Бриллиантов. - Москва : Проспект, 2014. - 111 с. - ISBN 978-5-392-16395-3.

3. Гареев, М. Ф. Цели иных мер уголовно-правового характера и средства их дос-тижения по российскому уголовному праву : диссертация на соискание ученой степени кандидата юридических наук / Гареев Марат Фаизович. Казань, 2005. - 198 с

4. Горобцов, В. И. Развитие теории уголовно-правового принуждения в новом Уголовном кодексе РФ / В. И. Горобцов // Актуальные проблемы теории уголовного права и правоприменительной практики : межвузовский сборник научных трудов. - Красноярск : КрВШ МВД РФ, 1997. - С. 60-67. - ISBN 5-7889-0002-6.

5. Грамматчиков, М. В. Судимость: исторический, уголовно-правовой и уголовно-исполнительный аспекты : автореферат диссертации на соискание ученой степени кандидата юридических наук / Грамматчиков Михаил Владимирович. - Красноярск, 2002. - 23 с.

6. Гребенкин, Ф. Б. Понятие, признаки и виды иных мер уголовно-правового характера / Ф. Б. Гребенкин // Системность в уголовном праве : Материалы II Российского Конгресса уголовного права. - Москва : Проспект, 2007. - С. $125-127$

7. Дуюнов, В. К. Уголовно-правовое воздействие: теория и практика / В. К. Дуюнов. - Москва : Научная книга, 2003. - 520 с. - ISBN 5-94935-019-7. 
8. Егоров, В. С. Вопросы правового регулирования мер уголовно-правового принуждения / В. С. Егоров. - Москва : Изд-во Московского психолого-социального ин-та ; Воронеж : Изд-во НПО «МОДЭК», 2006. - 309 с. - ISBN 5-89502-743-1 (МПСИ).

9. Ендольцева, А. В. Институт освобождения от уголовной ответственности: теоретические, законодательные и правоприменительные проблемы : автореферат диссертации на соискание ученой степени доктора юридических наук / Ендольцева Алла Васильевна. - Москва, 2005. - 50 с.

10. Загородников, Н. И. О пределах уголовной ответственности / Н. И. Загородников // Советское государство и право. - 1967. - № 7. - С. 39-46.

11. Звечаровский, И. Меры уголовно-правового характера: понятие, система, виды / И. Звечаровский // Законность. - 1999. - № 3. - С. 36-39.

12. Землюков, С. В. Понятие и содержание мер уголовно-правового характера / С. В. Землюков // Государство и право на рубеже веков : Криминология, уголовное право, судебное право : материалы Всероссийской конференции. - Москва : Ин-т государства и права РАН, 2001. - С. 29-36. - ISBN 5-8339-0027-3.

13. Калинина, Т. М. Административный надзор как иная мера уголовно-правового характера / Т. М. Калинина // Уголовное право: стратегия развития в XXI веке : материалы IX Международной научно-практической конференции. - Москва : Проспект, 2012. - С. 300-307. - ISBN 978-5-392-04825-0.

14. Каплин, М. Н. О мерах уголовно-правового характера / М. Н. Каплин // Актуальные проблемы дифференциации уголовной ответственности и законодательной техники в уголовном праве и процессе : сборник научных статей. - Ярославль : Изд-во Яросл. ун-та, 2003. - С. 169-176.

15. Карелин, Д. В. Принудительные меры воспитательного воздействия как альтернатива уголовной ответственности : диссертация на соискание ученой степени кандидата юридических наук / Карелин Дмитрий Владимирович. Томск, 2001. - 269 с.

16. Келина, С. Г. «Иные меры уголовно-правового характера» как институт уголовного права / С. Г. Келина // Уголовное право: стратегия развития в XXI веке : материалы 4-й Международной научно-практической конференции. Москва : Велби, 2007. - С. 283-288. - ISBN 978-5-482-01463-9.

17. Келина, С. Г. Меры ответственности, предусмотренные уголовным законом, и основания их применения / С. Г. Келина // Советское государство и право. - 1982. - № 5. - С. 100-108.

18. Келина, С. Г. Наказание и иные меры уголовно-правового характера / С. Г. Келина // Государство и право. 2007. - № 6. - С. 51-58.

19. Келина, С. Г. Теоретические вопросы освобождения от уголовной ответственности / С. Г. Келина. - Москва : Наука, 1974. - 231 с.

20. Кондалов, А. Н. Условное осуждение и механизмы его обеспечения : диссертация на соискание ученой степени кандидата юридических наук / Кондалов Александр Николаевич. - Казань, 2000. - 180 с.

21. Курганов, С. Меры уголовно-правового характера / С. Курганов // Уголовное право. - 2007. - № 2. - С. $59-63$.

22. Лесниченко, И. П. Понятие и основание уголовной ответственности : лекция / И. П. Лесниченко. - Ставрополь : Сервисшкола, 2005. - 59 с. - ISBN 5-93078-327-6.

23. Лопашенко, Н. А. Конфискация имущества / Н. А. Лопашенко. - Москва : Юрлитинформ, $2012 .-160$ с. ISBN 978-5-93295-984-8.

24. Магомедов, А. А. Уголовная ответственность и освобождение от нее: эволюция правовых воззрений и современность : автореферат диссертации на соискание ученой степени доктора юридических наук / Магомедов Асбег Ахмеднабиевич. - Москва, 1998. - 57 с.

25. Мальцев, В. В. Введение в уголовное право / В. В. Мальцев. - Волгоград : Волгогр. юрид. ин-т МВД России, 2000. - 204 с. - ISBN 5-7899-0093-3.

26. Мальцев, В. В. Проблемы освобождения от уголовной ответственности и наказания в уголовном праве / В. В. Мальцев. - Волгоград : ВА МВД России, 2004. - 209 с. - ISBN 5-7899-0293-6.

27. Медведев, Е. Понятие и виды иных мер уголовно-правового характера, применяемых за совершение преступлений / Е. Медведев // Уголовное право. - 2009. - № 5. - С. 46-51.

28. Медведев, Е. В. Понятие и сущность условного осуждения как инструмента уголовно-правового воздействия / Е. В. Медведев // Общество и право. - 2010. - № 2 (29). - С. 107-112.

29. Музеник, А. К. Дифференциация уголовной ответственности: формы и виды / А. К. Музеник // Уголовное право и современность : межвузовский сборник научных трудов. - Красноярск : КрВШ МВД РФ, 1998. - С. 21-26. ISBN 5-7889-0014-X.

30. Набиуллин, Ф. К. Некарательные меры уголовно-правового характера: природа, система и социально-правовое назначение : автореферат диссертации на соискание ученой степени кандидата юридических наук / Набиуллин Фарид Кавиевич. - Казань, 2008. - 23 с.

31. Назаренко, Г. В. Меры уголовно-правового характера, не являющиеся наказанием / Г. В. Назаренко // Уголовное право: стратегия развития в XXI веке : материалы XVII Международной научно-практической конференции. - Москва : РГ-Пресс, 2010. - С. 22-26. - ISBN 978-5-9988-0922-4.

32. Наумов, А. В. Российское уголовное право. Общая часть : курс лекций / А. В. Наумов. - Москва : Бек, 1996. 550 c. - ISBN 5-85639-125-X.

33. Непомнящая, Т. В. Наказание и меры уголовно-правового характера в системе мер противодействия преступности / Т. В. Непомнящая // Противодействие пре-ступности: уголовно-правовые, криминологические и уголовно-правовые аспек-ты : материалы III Российского Конгресса уголовного права. - Москва : Проспект, 2008. C. 86-89. - ISBN: 978-5-392-00279-5.

34. Непомнящая, Т. В. Проблемы назначения наказания : учебное пособие / Т. В. Непомнящая, В. М. Степашин. Омск : Изд-во Омского гос. ун-та, 2011. - 590 с.

35. Палтсер, А. Р. Освобождение от уголовной ответственности по советскому уголовному праву : автореферат диссертации на соискание ученой степени кандидата юридических наук / Палтсер Альберт Рудольфович. - Тарту, 1966. - $18 \mathrm{c}$.

36. Понятовская, Т. Г. Предупреждение преступлений: меры безопасности, административный надзор / Т. Г. Понятовская // Криминологический журнал Байкальского государственного университета экономики и права. - 2013. № 3. - С. 98-103.

37. Радаев, А. Г. О категории «меры уголовно-правового характера» / А. Г. Радаев // Уголовное право: стратегия развития в XXI веке : материалы Восьмой Международной научно-практической конференции. - Москва : МГЮА, 2011. - С. 318-322. - ISBN 978-5-392-02306-6.

38. Скобелин, С. Ю. Сущность и содержание мер уголовно-правового характера, альтернативных наказанию / С. Ю. Скобелин // Юридическая наука и правоохранительная практика. - 2009. - № 4 (10). - С. $57-62$. 
39. Скрипченко, Н. Ю. Правовое регулирование иных мер уголовно-правового характера: реалии и перспективы совершенствования / Н. Ю. Скрипченко // Уголовное право: стратегия развития в XXI веке : материалы IX Международной научно-практической конференции. - Москва : Проспект, 2012. - С. 289-293. - ISBN 978-5-392-04825-0. 40. Тарбагаев, А. Н. Ответственность в уголовном праве / А. Н. Тарбагаев // Известия высших учебных заведений. Правоведение. - 1994. - № 3. - С. 102-106.

41. Уголовное право России. Части Общая и Особенная : учебник / под редакцией А. В. Бриллиантова. - Изд. 2-е, перераб. и доп. - Москва : Проспект, 2015. - 1184 с. - ISBN 978-5-392-15428-9.

42. Уголовный кодекс Республики Беларусь : принят Палатой представителей 2 июня 1999 года : одобрен Советом Республики 24 июня 1999 года / ответственные редакторы Р. М. Асланов, А. И. Бойцов, Н. И. Мацнев. - СанктПетербург : Юридический центр Пресс, 2001. - 474 с. - ISBN 5-94-201-012-9.

43. Филимонов, В. Д. Уголовная ответственность по российскому законодательству / В. Д. Филимонов. - Москва : ЮрИнфоР-МГУ, 2008. - 247 с. - ISBN 978-5-91329-005-2.

44. Щедрин, Н. В. Российское уголовное право в контексте доктринальных моделей построения уголовно-правовых санкций / Н. В. Щедрин, О.М.Камылина // Криминологический журнал Байкальского государственного университета экономики и права. - 2008. - № 3. - С. 40-49.

\section{REFERENCES}

1. Borovikov S.A. Prinuditel'nye mery vospitatel'nogo vozdeistviya kak al'ternativa nakazaniyu nesovershennoletnikh [Compulsory measures of educational influence as an alternative to the punishment of minors]. Moscow: Yurlitinform, 2008. $192 \mathrm{p}$.

2. Brilliantov A.V. Osvobozhdenie ot ugolovnoi otvetstvennosti: s uchetom obobshcheniya sudebnoi praktiki: nauchnoprakticheskoe posobie [Exemption from criminal liability: taking into account the generalization of judicial practice: research and practice textbook]. Moscow: Prospekt, 2014. $111 \mathrm{p}$.

3. Gareev M.F. Tseli inykh mer ugolovno-pravovogo kharaktera i sredstva ikh dostizheniya po rossiiskomu ugolovnomu pravu: dissertatsiya na soiskanie uchenoi stepeni kandidata yuridicheskikh nauk [Goals of other criminal law measures and means of achieving them in Russian criminal law: Candidate of Sciences (Law) dissertation].Kazan, 2005.198 p.

4. Gorobtsov V.I. Development of the theory of criminal law enforcement in the new Criminal Code of the Russian Federation. In: Aktual'nye problemy teorii ugolovnogo prava i pravoprimenitel'noi praktiki: mezhvuzovskii sbornik nauchnykh trudov [Topical issues of the theory of criminal law and law enforcement practice: a collection of scientific papers]. Krasnoyarsk: KrVShMVDRF, 1997. Pp. 60-67. (In Russ.).

5. Grammatchikov M.V. Sudimost': istoricheskii, ugolovno-pravovoi i ugolovno-ispolnitel'nyi aspekty: avtoreferat dissertatsii na soiskanie uchenoi stepeni kandidata yuridicheskikh nauk [Criminal record: historical, criminal-legal and penal aspects: Candidate of Sciences (Law) dissertation abstract].Krasnoyarsk, 2002. 23 p.

6. Grebenkin F.B. The concept, features and types of other measures of a criminal-legal nature. In: Sistemnost' $v$ ugolovnom prave: Materialy II Rossiiskogo Kongressa ugolovnogo prava [Consistency in criminal law. Proceedings of the second Russian Congress on Criminal Law]. Moscow: Prospekt, 2007. Pp. 125-127. (In Russ.).

7. Duyunov V.K. Ugolovno-pravovoe vozdeistvie: teoriya i praktika [Criminal law impact: theory and practice]. Moscow: Nauchnaya kniga, 2003. 520 p.

8. Egorov V.S. Voprosy pravovogo regulirovaniya mer ugolovno-pravovogo prinuzhdeniya [Issues of legal regulation of criminal law enforcement measures]. Moscow: Izd-vo Moskovskogo psikhologo-sotsial'nogo in-ta; Voronezh: Izd-vo NPO "MODEK", 2006. 309 p.

9. Endol'tseva A.V. Institut osvobozhdeniya ot ugolovnoi otvetstvennosti: teoreticheskie, zakonodatel'nye i pravoprimenitel'nye problemy: avtoreferat dissertatsii na soiskanie uchenoi stepeni doktora yuridicheskikh nauk [Institute of exemption from criminal liability: theoretical, legislative and law enforcement problems: Doctor of Sciences (Law) dissertation abstract]. Moscow, 2005. 50 p.

10. Zagorodnikov N.I. On the limits of criminal liability. Sovetskoe gosudarstvo i pravo = Soviet State and Law, 1967, no. 7 , pp. 39-46. (In Russ.).

11. Zvecharovskii I. Criminal law measures: concept, system, types. Zakonnost'=Legality, 1999, no. 3, pp. 36-39. (In Russ.).

12. Zemlyukov S.V. The concept and content of criminal law measures.In: Gosudarstvo i pravo na rubezhe vekov: Kriminologiya, ugolovnoe pravo, sudebnoe pravo: materialy Vserossiiskoi konferentsii [State and law at the turn of the century:Criminology, criminal law, judicial law: Proceedings of the all-Russian conference]. Moscow: In-t gosudarstva i prava RAN, 2001. Pp. 29-36. (In Russ.).

13. Kalinina T.M. Administrative supervision as another measure of criminal law. In: Ugolovnoe pravo: strategiya razvitiya $v$ XXI veke: materialy IX Mezhdunarodnoi nauchno-prakticheskoi konferentsii [Criminal law: development strategy in the 21st century. Proceedings of the 9th research-to-practice conference]. Moscow: Prospekt, 2012. Pp. 300-307. (In Russ.).

14. Kaplin M.N. On criminal law measures. In: Aktual'nye problemy differentsiatsii ugolovnoi otvetstvennosti i zakonodatel'noi tekhniki v ugolovnom prave i protsesse: sbornik nauchnykh statei. Yaroslavl: Izd-vo Yarosl. un-ta, 2003. Pp. 169-176. (In Russ.).

15. Karelin D.V. Prinuditel'nye mery vospitatel'nogo vozdeistviya kak al'ternativa ugolovnoi otvetstvennosti: dissertatsiya na soiskanie uchenoi stepeni kandidata yuridicheskikh nauk [Compulsory measures of educational influence as an alternative to criminal liability:Candidate of Sciences (Law) dissertation]. Tomsk, 2001. 269 p.

16. Kelina S.G. "Other measures of a criminal law nature" as an institute of criminal law.In: Ugolovnoe pravo: strategiya razvitiya v XXI veke: materialy 4-i Mezhdunarodnoi nauchno-prakticheskoi konferentsii [Criminal law: development strategy in the 21st century. Proceedings of the 4th international research-to-practice conference]. Moscow: Velbi, 2007. Pp. 283-288. 17. Kelina S.G. Measures of responsibility provided for by the criminal law and the grounds for their application. Sovetskoe gosudarstvo i pravo = Soviet State and Law, 1982, no. 5. pp. 100-108. (In Russ.).

18. Kelina S.G. Punishment and other criminal law measures. Gosudarstvo i pravo = State and Law, 2007, no. 6. pp. 51-58. (In Russ.)

19. Kelina S.G. Teoreticheskie voprosy osvobozhdeniya ot ugolovnoi otvetstvennosti [Theoretical issues of exemption from criminal liability]. Moscow: Nauka, 1974. $231 \mathrm{p}$.

20. Kondalov A.N. Uslovnoe osuzhdenie i mekhanizmy ego obespecheniya: dissertatsiya na soiskanie uchenoi stepeni kandidata yuridicheskikh nauk [Suspended sentence and mechanisms of its provision: Candidate of Sciences (Law) dissertation]. Kazan, 2000. 180 p.

21. Kurganov S. Criminal law measures. Ugolovnoe pravo = Criminal Law, 2007, no. 2, pp. 59-63. (In Russ.).

22. Lesnichenko I.P. Ponyatie i osnovanie ugolovnoi otvetstvennosti: lektsiya [The notion and basis of criminal liability: a lecture]. Stavropol: Servisshkola, 2005. 59 p. 
23. Lopashenko N.A. Konfiskatsiya imushchestva [Confiscation of property]. Moscow: Yurlitinform, 2012. 160 p.

24. Magomedov A.A. Ugolovnaya otvetstvennost' i osvobozhdenie ot nee: evolyutsiya pravovykh vozzrenii i sovremennost': avtoreferat dissertatsii na soiskanie uchenoi stepeni doktora yuridicheskikh nauk [Criminal liability and exemption from it: evolution of legal views and modernity:Doctor of Sciences (Law) dissertation abstract]. Moscow,1998. $57 \mathrm{p}$.

25. Mal'tsev V.V. Vvedenie v ugolovnoe pravo [Introduction to criminal law]. Volgograd: Volgogr. yurid. in-t MVD Rossii, 2000. $204 \mathrm{p}$.

26. Mal'tsev V.V. Problemy osvobozhdeniya ot ugolovnoi otvetstvennosti i nakazaniya $v$ ugolovnom prave [Problems of exemption from criminal liability and punishment in criminal law]. Volgograd: VA MVD Rossii, 2004. 209 p.

27. Medvedev E. The concept and types of other criminal law measures applied for the commission of crimes. Ugolovnoe pravo $=$ Criminal Law, 2009, no. 5, pp. 46-51. (In Russ.).

28. Medvedev E.V. The concept and essence of suspended sentence as a tool of criminal law impact. Obshchestvo i pravo = Society and Law, 2010, no. 2 (29), pp. 107-112. (In Russ.).

29. Muzenik A.K. Differentiation of criminal liability: forms and types. In: Ugolovnoe pravo i sovremennost': mezhvuzovskii sbornik nauchnykh trudov [Criminal law and modernity. Inter-university collection of scientific papers]. Krasnoyarsk: KrVSh MVD RF, 1998. Pp. 21-26. (In Russ.).

30. Nabiullin F.K. Nekaratel'nye mery ugolovno-pravovogo kharaktera: priroda, sistema i sotsial'no-pravovoe naznachenie: avtoreferat dissertatsii na soiskanie uchenoi stepeni kandidata yuridicheskikh nauk [Non-punitive criminal-legal measures: nature, system and socio-legal purpose: Candidate of Sciences (Law) dissertation abstract]. Kazan, 2008. 23 p.

31. Nazarenko G.V. Criminal law measures that are not a punishment. In: Ugolovnoe pravo: strategiya razvitiya $v$ XXI veke: materialy XVII Mezhdunarodnoi nauchno-prakticheskoi konferentsii [Criminal law: development strategy in the 21st century:Proceedings of the 17th international research-to-practice conference]. Moscow: RG-Press, 2010. Pp. 22-26. 32. Naumov A.V. Rossiiskoe ugolovnoe pravo. Obshchaya chast': kurs lektsii [Russian criminal law. General part. A course of lectures]. Moscow: Bek, 1996. 550 p.

33. Nepomnyashchaya T.V. Punishment and measures of criminal law in the system of measures to counter crime. In: Protivodeistvie prestupnosti: ugolovno-pravovye, kriminologicheskie i ugolovno-pravovye aspekty: materialy III Rossiiskogo Kongressa ugolovnogo prava [Combating crime: criminal law, criminological and criminal law aspects: Proceedings of the 3rd Russian Congress on criminal law]. Moscow: Prospekt, 2008. Pp. 86-89.

34. Nepomnyashchaya T.V., Stepashin V.M. Problemy naznacheniya nakazaniya: uchebnoe posobie [Problems of sentencing: a textbook]. Omsk: Izd-vo Omskogo gos. un-ta, 2011. 590 p.

35. Paltser A.R. Osvobozhdenie ot ugolovnoi otvetstvennosti po sovetskomu ugolovnomu pravu: avtoreferat dissertatsii na soiskanie uchenoi stepeni kandidata yuridicheskikh nauk [Exemption from criminal liability under Soviet criminal law: Candidate of Sciences (Law) dissertation abstract]. Tartu, 1966. 18 p.

36. Ponyatovskaya T.G. Crime prevention: security measures, administrative supervision. Kriminologicheskii zhurnal Baikal'skogo gosudarstvennogo universiteta ekonomiki i prava = Criminology Journal of Baikal National University of Economics and Law, 2013, no. 3, pp. 98-103. (In Russian).

37. Radaev A.G. About the notion of "measures of criminal law". In: Ugolovnoe pravo: strategiya razvitiya $v$ XXI veke: materialy Vos'moi Mezhdunarodnoi nauchno-prakticheskoi konferentsii [Criminal law: development strategy in the 21st century:Proceedings of the 8th international research-to-practice conference]. Moscow: MGYuA, 2011. Pp. 318-322.

38. Skobelin S.Yu. The essence and content of criminal law measures, alternative to punishment. Yuridicheskaya nauka $i$ pravookhranitel'naya praktika = Legal Science and Law Enforcement Practice, 2009, no. 4 (10), pp. 57-62. (In Russ.). 39. Skripchenko N.Yu. Legal regulation of other criminal law measures: realities and prospects for improvement. In: Ugolovnoe pravo: strategiya razvitiya $v$ XXI veke: materialy IXMezhdunarodnoi nauchno-prakticheskoi konferentsii [Criminal law: development strategy in the 21st century: Proceedings of the 9th international research-to-practice conference]. Moscow: Prospekt, 2012. Pp. 289-293.

40. Tarbagaev A.N. Responsibility in criminal law. Izvestiya vysshikh uchebnykh zavedenii. Pravovedenie $=$ Proceedings of Higher Educational Institutions. Pravovedenie, 1994, no. 3, pp. 102-106. (In Russ.).

41. BrilliantovA.V. (Ed.). Ugolovnoe pravo Rossii. Chasti Obshchaya i Osobennaya: uchebnik [Criminal law of Russia. The general and the special part: a textbook]. Moscow, 2008. $1180 \mathrm{p}$.

42. Aslanov R.M., Boitsov A.I., Matsnev N.I. (Eds.). Ugolovnyi kodeks Respubliki Belarus' [Criminal Code of the Republic of Belarus]. Saint Petersburg: Yuridicheskii tsentr Press, 2001. $474 \mathrm{p}$.

43. Filimonov V.D. Ugolovnaya otvetstvennost' po rossiiskomu zakonodatel'stvu [Criminal liability under Russian legislation]. Moscow: YurInfoR-MGU, 2008. $247 \mathrm{p}$.

44. Shchedrin N.V., Kamylina O.M. Russian criminal law in the context of doctrinal models of building criminal law sanctions. Kriminologicheskii zhurnal Baikal'skogo gosudarstvennogo universiteta ekonomiki i prava = Criminology Journal of Baikal National University of Economics and Law, 2008, no. 3, pp. 40-49. (In Russ.).

\section{CВЕДЕНИЯ ОБ АВТOPE / INFORMATION ABOUT THE AUTHOR}

ЮРИЙ ЕВГЕНЬЕВИЧ ПУДОВОЧКИН - дОктор юридИческих наук, профессор, главный научный сотрудник руководитель уголовно-правового направления Центра исследований проблем правосудия Российского государственного университета правосудия, г. Москва, Российская Федерация. ORCID: https://orcid. org/00000003-1100-9310, e-mail: 11081975@list.ru
YURII E. PUDOVOCHKIN - Doctor of Sciences (Law), Professor, chief researcher, head of the criminal law direction at the Center for Justice Research of the Russian State University of Justice, Moscow, Russian Federation. ORCID: https://orcid. org/0000-0003-1100-9310, e-mail: 11081975@list.ru 